\title{
Understanding the needs of nutrition intake on athletes
}

\author{
Sasmarianto* $^{\circledR}$, Raffly Henjilito ${ }^{\circledR}$, Zulrafli \\ Kamarudin $^{\circledR}$, Novia Nazirun ${ }^{\circledR}$ \\ Universitas Islam Riau, Indonesia
}

Received: 01 March 2021; Accepted 27 June 2021; Published 31 July 2021

Ed 2021; 6(2): 244-253

\begin{abstract}
Physical fitness is influenced by the food they consume. Nutritious food can increase the athlete's stamina so that athlete's achievement will be easily achieved. Fulfilling the need for nutritional intake requires a good level of understanding of the importance of the nutritional intake needs of athletes, especially football athletes at SMA Negeri Sport Riau Province. The purpose of the study is to measure the level of understanding of the nutritional intake needs of adolescent football athletes at SMA Negeri Sport Riau Province. This type of research is evaluation. The method used in this study is a survey method with data collection techniques using a questionnaire. The data collection technique is carried out using a questionnaire or questionnaire method by testing the level of validity and reliability. The population in the study amounted to 35 male football athletes at the Riau Province Sports State Senior High School. The sampling technique uses total sampling. Data analysis uses quantitative descriptive as outlined in the form of a percentage. The results shows that the level of understanding of the nutritional intake needs of football athletes at the Riau Province Sports High School can be seen that $65.7 \%$ gives a good assessment. This indicates that the level of understanding of the nutritional needs of athletes is in the good category so this needs to be maintained. Likewise, the athletes' understanding of the athlete's daily nutritional adequacy and the regulation of the athlete's nutritional intake during the training period is in the good category. So it can be concluded that the level of understanding of the nutritional intake needs of football athletes is in the good category.
\end{abstract}

Keywords: Comprehension level; nutritional intake; athletes; football

https://doi.org/10.25299/sportarea.2021.vol6(2).6509

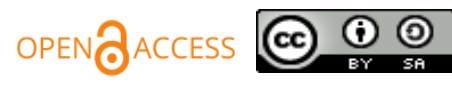

Copyright @ 2021 Sasmarianto, Raffly Henjilito, Zulrafli, Kamarudin, Novia Nazirun

Correspondingauthor: Sasmarianto, Department of Physical Education, Health and Recreation, Faculty of Teacher Training and Education, Universitas Islam Riau, Pekanbaru, Indonesia

Email: sasmarianto@edu.uir.ac.id

How to Cite: Sasmarianto., Henjilito, R., Zulrafli., Kamarudin., \& Nazirun, N. (2021). Understanding the needs of nutrition intake on athletes. Journal of Sport Area, 6(2), 244-253. https://doi.org/10.25299/sportarea.2021.vol6(2).6509

\section{INTRODUCTION}

An athlete's physical health can be achieved by meeting nutritional needs in accordance with the characteristics of the athlete's sport. Fulfillment of a balanced nutritional intake can produce the energy needed by an athlete when practicing or competing (Malara et al., 2013). The nutritional intake needs of an athlete are specific due to the characteristics of physical intensity and sport (Spronk et al., 2015). Therefore, to create athletes who excel, balanced nutrition is a very important aspect to pay attention (Siregar et al., 2018).

Achieving maximum performance requires an optimal training system, including the availability and adequacy of nutrition according to the type of sport. Every athlete must pay attention to the fulfillment of their nutritional intake, especially on the balance between energy intake and expenditure, both in the phases before, during, and after training or competing (Hapsari et al., 2018). Athletes who get nutritional intake 
according to individual characteristics and sports will be able to improve their performance well (Mukarromah et al., 2017). Excellent performance will support athletes in obtaining achievements (Mustamin et al., 2010).

The level of knowledge of sports nutrition and eating arrangements of an athlete is the key in achieving maximum performance (Nazhif et al., 2016). Improved athlete performance comes from consuming a balanced diet of nutrients. Proper and balanced nutritional intake can be seen in terms of the quality and quantity of food that can produce optimal physical conditions, and provide sufficient energy for athletes during the training process. Fulfillment of balanced nutritional needs can be achieved if the athlete's understanding of food regulation is implemented properly (Afriani et al., 2017).

Understanding the nutritional needs of an athlete can be maximized by increasing the athlete's knowledge about the importance of fulfilling nutritional needs according to the daily nutritional adequacy rate (RDA) required by athletes according to the characteristics of the sport (Spronk et al., 2015). If the source of energy in the body is sufficient, an athlete will be able to train and compete to the maximum so that the best performance will be easily achieved (Pritchett et al., 2009). The fulfillment of nutritional needs must be supported by the knowledge of athletes in managing and maintaining a balance of their daily nutritional needs (Dhesa et al., 2020).

One of the sports that require balanced nutrition is football. Football is a sport that is very much favored by all levels of society (Devlin et al., 2017). The sport of football has become an industry in many countries. Achievements in football have become an economic comedy that can be turned into a business so as to produce material from both players, coaches, and football clubs (Irdilla et al., 2016). Therefore, the improvement of athlete achievement is to build schools and academies for football for students. One of the policies is to establish efforts to improve nutrition in institutions such as sports training centers.

Football athletes need to be in very good physical condition. Football is a type of sport with a fast movement tempo and lasts for a long duration, this of course drains a lot of energy and stamina (Alfitasari et al., 2019). The stamina of a good athlete is also supported by a balanced nutritional intake. Nutritional balance can be seen in terms of the type, quantity and quality of food ingredients that can be processed into food so as to produce nutrients that are useful for the athlete's body and optimal physical condition. An athlete's diet must contain nutrients in accordance with those needed to meet energy needs during daily activities and sports (Siregar et al., 2018).

Adolescent athletes must meet the needs of energy intake and macronutrients, especially protein intake which is very much needed during the growth period (Rachmayani et al., 2018). This is due to the higher physical activity of athletes compared to non-athletes so that more energy intake is needed for metabolism and hormone synthesis (Mardiana \& Prameswari, 2019). Fulfilling the nutritional intake of adolescent athletes need to pay attention to the level of adequacy or dosage in feeding so that it can produce balanced energy for the athlete's body. Proper nutrition will improve the performance of adolescent athletes in training and competition. An understanding of the importance of athlete nutrition is very basic in the process of fulfilling the nutritional needs of adolescent athletes (Beelen et al., 2010).

The level of understanding of the intake needs of adolescent athletes should be supported by increasing knowledge through education (Wulandini \& Hamdani, 2013). Nutrition education can be provided by team or school management which aims to increase the knowledge and understanding of adolescent athletes regarding nutritional intake needs (Devlin et al., 2017). With nutrition education provided at training centers and gifted schools for adolescent athletes, it will increase the athlete's nutritional knowledge and will affect attitudes and behavior in food selection which will ultimately affect the athlete's nutrition (Jamalong, 2014).

Sports gifted schools are centers for fostering adolescent athletes and almost all provinces in Indonesia, one of which is Riau Province. Riau Province Sports High School is the only sports-based school in Riau Province. Founded in 2012 by combining the concept of curriculum 13 and the development of expertise in the field of sports. Athletes in the Sports State High School are given coaching and training with talent development programs compiled by school management.

Based on the results of observations in the field of football athletes at the Riau Province State Sports High School, there are phenomena that occur. Researchers found that nutrition education has not been 
implemented in schools that can increase understanding of the nutritional needs of football athletes. Limited nutritionist consultants and limited nutritionists who can provide nutritional counseling to athletes. The football athletes of the Riau Province State Sports High School do not receive any supervision from the school management or nutritionists so that the possibility of an incompatibility of the athlete's nutritional needs is very large. Likewise, the provision of fluid intake in the form of electrolyte fluids and other mineral intakes that are not routinely given to athletes during training, competing or after matches or training. The problems that researchers found in the field are in line with research conducted by Wulandini and Hamdani, (2013) that athletes in the Riau Province Sports Public High School are expected to increase knowledge about nutrition and to teaching staff in high school so that they can socialize and provide health education in a holistic manner continue to students about the nutritional status of athletes.

Previous research found that a good knowledge of nutritional intake needs will affect the performance of athletes (Trakman et al., 2017). Fulfillment of nutritional intake which is a basic need for adolescent athletes to carry out daily activities and sports and will ultimately affect achievement (Ameryk et al., 2016). Research from Ono et al., (2012) the result of his research is that an adequate diet is very important for the optimal performance of professional football players. Research result Alaunyte et al., (2015) revealed that the majority of rugby athletes have low knowledge of food management. In research Arsani, Agustini, and Sudarmada (2014) who found that the regulation of nutritional intake needs is carried out by the athletes themselves and their parents. Research results from Mandosir and Sinaga (2017) concluded that the ideal management staff and food implementation generally worked well, except for processing because sometimes the menu served does not match the master menu. Although there have been many studies on the level of understanding of nutritional needs in athletes, there has been no research that reports the level of understanding of nutritional needs in athletes in terms of indicators of suitability of doses and food settings. In addition, previous studies only examined the level of understanding of athletes' nutrition separately and did not include indicators of the suitability of the dose and diet of football athletes together. Football athletes really need high energy with good knowledge of proper nutritional adequacy that will improve the performance of football athletes in training and competing. Therefore, there is a need for improvement from school management to provide education in meeting the nutritional needs of football athletes.

\section{METHOD}

This research method uses an evaluation research approach. This research is conducted at the Riau Province Sports Public High School and is carried out in November 2019. The population in this study is all 35 football athletes at the Riau Province Sports High School. The sample in this study are all 35 football athletes at SMA Negeri Sport Riau Province with a total sampling technique. The data collection technique is carried out using a questionnaire or questionnaire method, amounting to 60 statements. To get the level of validity of an instrument, the level of validity and reliability is tested. The rxy value obtained is consulted with the product moment formula in the table at a significance level of 0.05 . While the reliability of the instrument is done to see that the instrument is reliable enough to be used as a data collection tool. The data analysis technique in this study uses descriptive quantitative data analysis techniques. The calculation of descriptive statistics uses descriptive statistics of percentages, because those included in descriptive statistics include the presentation of data through tables, graphs, and percentages (Stufflebeam \& Coryn, 2014). This is done to answer the problems contained in the research conducted.

\section{RESULTS AND DISCUSSION}

\section{Level of Understanding of Nutritional Needs}

The level of understanding of the nutritional intake needs of football athletes is obtained through a questionnaire that has been distributed totaling 60 statements. After the research data is collected, an analysis is carried out on the statement items distributed to the football athletes of the Riau Province Sports State High School. The results of the study can be seen in detail in Table 1 as follows: 
Table 1. Level of Understanding of Nutritional Needs of Football Athletes

\begin{tabular}{cccc}
\hline No & Category & Frequency & \% \\
\hline 1 & Very Good & 8 & 22,9 \\
2 & Good & 23 & 65,7 \\
3 & Enough & 2 & 5,71 \\
4 & Less & 2 & 5,71 \\
\hline & Amount & $\mathbf{3 5}$ & $\mathbf{1 0 0 \%}$ \\
\hline
\end{tabular}

The level of understanding of the nutritional intake needs of football athletes can be seen in the graph below.

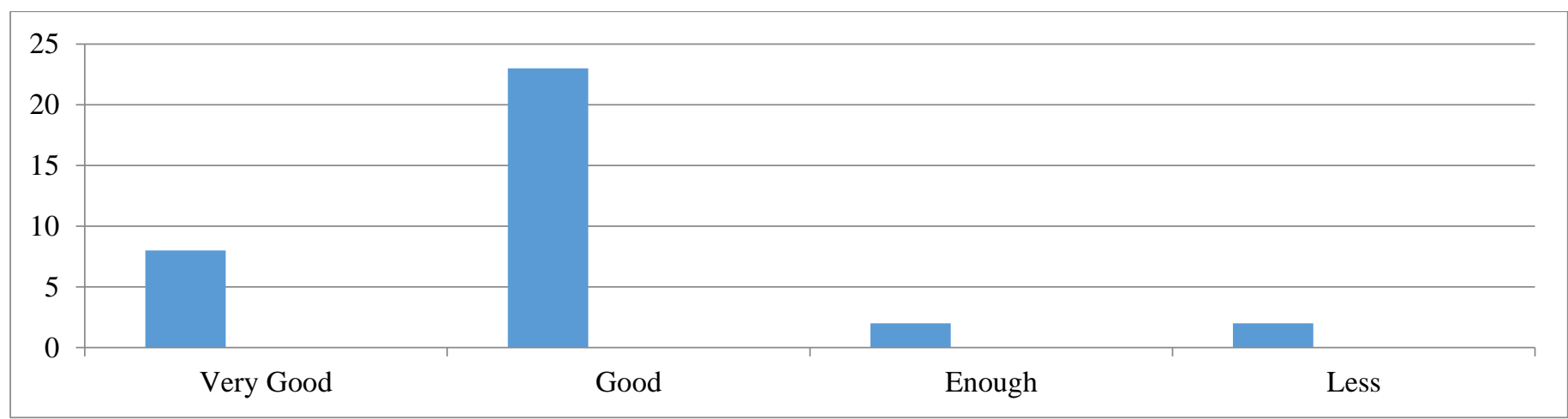

Graph 1. Level of Understanding of Nutritional Needs of Athletes

From the data presented in Table 1, the data on the level of understanding of the athletes obtained the following results: (1) 8 athletes from SMA Negeri Sports or $22.9 \%$ gave very good ratings, (2) 23 athletes or $65.7 \%$ gave good ratings., (3) 2 athletes or $5.71 \%$ gave a sufficient rating, (4) 2 athletes or $5.71 \%$ gave a poor rating.

Details of the level of understanding of the nutritional intake needs of athletes at SMA Negeri Sport Riau Province based on the factors that influence the level of understanding of athletes on meeting the nutritional needs of athletes can be seen as follows:

\section{a. Factors for Athletes' Nutritional Intake Doses}

The results of the study on the level of understanding of the nutritional intake needs of athletes at the State Sports High School Riau Province based on the suitability of the athlete's nutritional intake are presented in Table 2 as follows:

Table 2. Factors for Athletes' Nutritional Intake Doses

\begin{tabular}{cccc}
\hline No & Category & Frequency & \% \\
\hline 1 & Very Good & 5 & 14,29 \\
2 & Good & 20 & 57,14 \\
3 & Enough & 5 & 14,29 \\
4 & Less & 5 & 14,29 \\
\hline
\end{tabular}

When displayed in graphic form, the data on the level of understanding of the nutritional intake needs of the athletes at the Sports High School of Riau Province based on the suitability factor for the athlete's nutritional intake can be seen in Figure 2 as follows: 


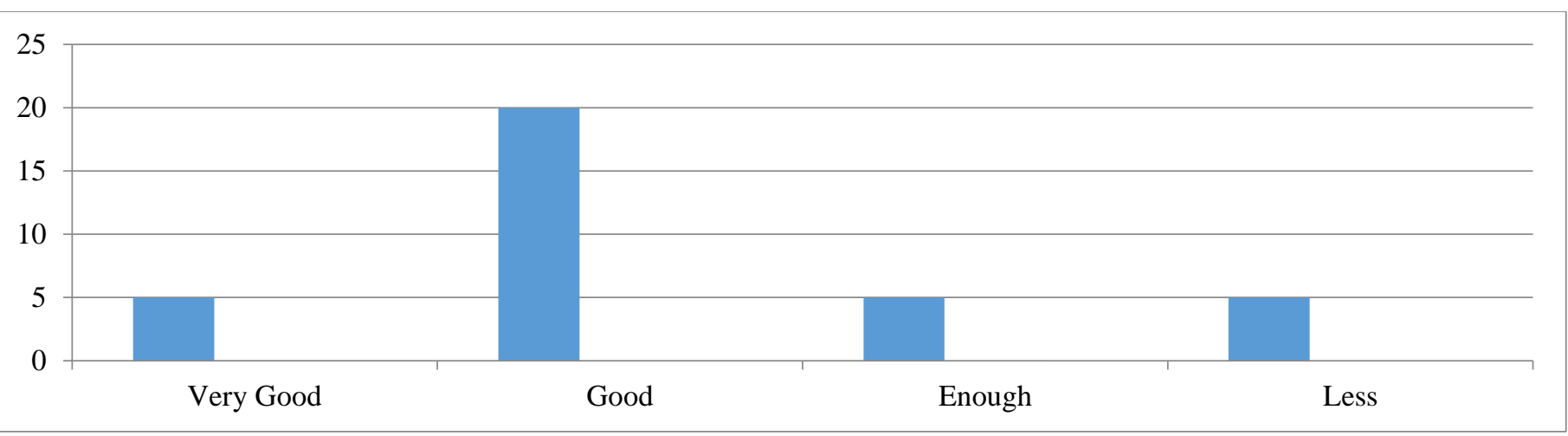

Figure 2. Graph of Factors for Athletes' Nutritional Intake Doses

The suitability factor for the nutritional intake of athletes based on table 2 and figure 2 above, shows that the level of understanding of the nutritional intake needs of football athletes at SMA Negeri Sport Riau Province based on the suitability factor for athletes' nutritional intake is in the "very poor" category of $0 \%(0$ athlete), the "less" category is $14.29 \%$ (5 athletes), the "enough" category is $14.29 \%$ (5 athletes), the "good" category is 57.14 (20 athletes), the "very good" category is 14, 29\% (5 athletes). Based on the average percentage of $57.14 \%$ the level of understanding of nutritional intake needs based on the suitability factor for the athlete's nutritional intake is included in the "good" category.

\section{b. Factors for Athletes' Nutritional Intake Regulation on Training Periodesation}

The goal of regulating the nutritional intake of athletes is to find the best diet and increase the efficiency of the body's metabolism to face training and competitions. The benefit is that athletes can maximize their performance through consumption of foods that are in accordance with their nutrition so that athlete's achievement can be improved (Kuswari et al., 2021). The results of the study on the level of understanding of the nutritional intake needs of football athletes at SMA Negeri Sport Riau Province based on factors that regulate the nutritional intake of athletes in the period of exercise are presented in Table 3 as follows:

Table 3. Factors of Appropriateness of Athletes Nutritional Intake Doses

\begin{tabular}{cccc}
\hline No & Category & Frequency & \% \\
\hline 1 & Very Good & 3 & 8,57 \\
\hline 2 & Good & 27 & 77,1 \\
\hline 3 & Enough & 3 & 8,57 \\
\hline 4 & Less & 2 & 5,71 \\
\hline
\end{tabular}

When displayed in graphical form, the data on the level of understanding of the nutritional intake needs of athletes at the State High School Sports Riau Province based on the factors that regulate the nutritional intake of athletes in the period of exercise can be seen in Figure 3 as follows:

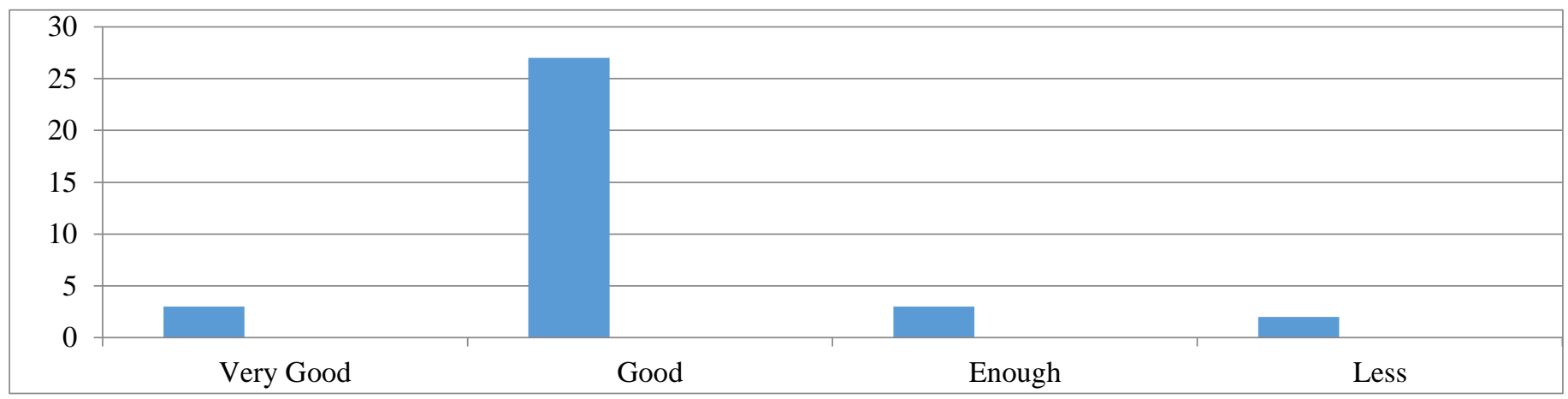

Figure 3. Graph of Factors of Athletes Nutritional Intake Regulation on Training Periodesation 
The factor of regulating the nutritional intake of athletes in the exercise period based on table 3 and figure 3 above, shows that the level of understanding of the nutritional intake needs of the athletes at the State High School Sports Riau Province based on the factor of regulating the nutritional intake of athletes in the exercise period is in the "very poor" category of $0 \%$ ( 0 athletes), the "less" category is $5.71 \%$ (2 athletes), the "enough" category is $8.57 \%$ ( 3 athletes), the "good" category is $77.1 \%$ ( 27 athletes), the "very good" by $8.57 \%$ (3 athletes). Based on an average percentage of $77.1 \%$, the level of understanding of nutritional intake needs based on factors regulating athletes' nutritional intake during exercise periodization is in the "good" category.

The level of understanding of the nutritional intake needs of football athletes is in the good category range with $65.7 \%$ results. From the results of the data presented above regarding the level of understanding of football athletes, it can be interpreted that athletes provide a good response to the nutritional adequacy system carried out by school management. However, in daily practice, many athletes and coaches do not understand the athlete's diet. Syafrizar and Welis (2009) explained that, one of the bases to maintain the highest condition of physical efficiency and sports performance is optimal nutrition.

Football athletes at SMA Negeri Sports understand how important it is to get used to a healthy lifestyle by consuming foods rich in nutrients by adopting a regular diet. Every athlete must pay attention to the fulfillment of their nutritional intake, especially the balance between energy intake and expenditure, both in the phases before, during, and after training or competing. Athletes who get nutritional intake according to individual characteristics and sports will have sufficient nutrition to practice and improve performance. Good performance from athletes will support athletes to get their best achievements (Kuswari et al., 2021).

Football athletes at SMA Negeri Sports are athletes as well as students who focus on training and learning. Increasing the athlete's understanding of nutrition can be provided with nutrition education. Ameryk et al., (2016) in their research concluded that nutritional education for young athletes (football players) is needed to improve eating habits and improve physical performance. Arrangements for the fulfillment of the food needs of the SMA Negeri Sports football athletes need to be supervised. Supervision of the athlete's diet is very necessary. Supervision of the athlete's diet needs to be carried out regularly and programmed. In a study conducted by Ozdoğan and Ozcelik (2011) concluded that the exercise process with the aim of increasing achievement in the field of sports, optimal food arrangements must get the attention of everyone involved. The monitoring process can be carried out by school management and trainers.

The suitability of the nutritional dose of the football athletes of the Riau Province Sports State High School needs attention from the school management. The balance of doses in balanced nutrition can affect the stamina and strength of athletes so that achievement will be easily achieved. Athletes need a balance of nutrition, consumption of carbohydrates to prevent fatigue and maintain glucose levels in the bloodstream (Jeukendrup \& Randell, 2011).

Sports State High School football athletes get knowledge Sports State high school football athletes gain knowledge about sports nutrition from several sources, such as coaches and the media. In the research of Spronk et al., (2015) which is to compare the level of nutritional knowledge between the athlete group and the non-athlete group. Athletes' knowledge is better than non-athletes. In line with research conducted by Mukarromah et al., (2017) concluded that the level of nutritional knowledge of athletes in PPLOP Central Java Province is classified as good as much as $60 \%, 30 \%$ is classified as sufficient and $10 \%$ is classified as lacking.

In the research of Anitasari et al., (2019) concluded that, in order to be able to excel, apart from regular exercise, athletes must also be able to optimally regulate the portion of food consumed. Fulfillment of nutritional intake both in quantity and type will improve the performance of athletes including the fulfillment of carbohydrate, protein, and other micro and macro nutrients (Masdewi et al., 2011). Thus, nutrients continue to develop into a very important element in supporting athlete achievement.

In order for performance to improve and satisfy, athletes need adequate nutrition in both quality and quantity (Reñón \& Collado, 2015). It should be noted that in meeting the nutritional needs of football athletes at the Riau Province Sports High School, it is necessary to calculate the number of calories needed to carry out physical activity. In every physical activity carried out, athletes require energy and calorie intake 
while the energy and calories are obtained from the food they consume daily. If energy needs cannot be fulfilled optimally, it will have an impact on decreasing body condition which may cause disease (Kurnia et al., 2020). The energy expended must be balanced or equal to the energy entered from food.

Research conducted by Meng et al., (2018) shows that the level of nutritional needs of each athlete is different according to the characteristics and branches of the sport. In line with the research of Hapsari et al. (2018) based on the findings of his research concluded that athletes, coaches, and sports management must know the nutritional status of each player because of its significant influence on the performance of an athlete.

Meeting the energy needs of an athlete can be seen from the size of the body, physical, and training activities. Nutritional intake needs are individual for each athlete and sport. Measuring nutritional needs must take into account age, gender, food preferences, food intolerances or allergies, and other special needs. The number of problems that are often found in athletes are related to low knowledge of sports nutrition, less varied food menus and there are still many athletes who prioritize the use of supplements compared to other factors (Kuswari et al., 2021). In addition, increased performance and achievement does not only come from regular exercise, but needs to be supported by a balanced and regular intake of nutrients (Mustamin et al., 2010).

The nutritional needs of the SMA Negeri Sports football athletes must also be supported by additional nutritional intake. Supplementary food is needed to continue to maintain the athlete's performance in the form of a snack bar or energy drink Goulet (2012) additional food is useful for balancing and complementing the needs of an athlete's body. According to research Ozdoğan and Ozcelik (2011)a the nutritional intake of athletes must be supported by additional food in the form of supporting foods such as supplements. The nutritional balance of athletes is the main goal in improving the ability and fitness of the body so that it can support athletes in achieving achievements.

Football athletes must be able to identify the main goal of fulfilling nutritional intake where energy needs can be obtained from carbohydrates, proteins, fats, vitamins, and minerals that are important for the body to support the body's performance and performance so as to increase stamina in training. Football athletes need energy intake from the breakdown of nutrients, namely fat, carbohydrates and protein. Before identifying nutrition providers, athletes must know good nutritional status to maintain a balanced degree of nutritional intake in the body. This can be done by examining the body mass index and nutritional status of an athlete. Heikkilä (2015) explains that developing adequate nutritional knowledge in order to understand the importance of dietary regulation in young athletes so that it will support athlete achievement.

\section{CONCLUSION}

Based on the data analysis and discussion of the findings of this study, it can be concluded that, the level of understanding of the nutritional intake needs of football athletes at SMA Negeri Sport Riau Province can be seen that $65.7 \%$ gave a good assessment. This indicates that the level of understanding of the nutritional needs of athletes is in the good category so this needs to be maintained. Likewise, the athlete's understanding of the athlete's daily nutritional adequacy and the regulation of the athlete's nutritional intake in the exercise period is in the good category. So it can be concluded that the level of understanding of the nutritional intake needs of football athletes is included in the "good" category.

Limitations in this study can be stated, among others, the number of other variables that affect the level of understanding of nutritional intake needs in athletes such as school management policy variables, funding and budgeting for athletes' dietary needs, athlete nutritional status, and the role of parents in supporting the nutritional needs of athletes. The breadth of the scope of this research cannot be reached by researchers and is beyond the control of researchers so that researchers limit the variables studied on the daily nutritional adequacy of athletes and the regulation of athletes' nutritional intake. As well as the lack of information about meeting the nutritional needs of athletes sourced from school management, school management has not yet fully provided complete information about meeting the needs of football athletes at SMA Negeri Sport Riau Province. The results of this study are expected to later be used as a reference for further research by considering other factors that affect the level of understanding of the 
nutritional intake needs of football athletes which can indirectly affect athlete achievement. Suggestions for further research are that data collection will be better if accompanied by data triangulation or data validity and this research only discusses the level of understanding of nutritional intake needs, it would be better if it is equipped with analysis to determine the factors that influence the understanding of athletes' nutritional needs.

\section{REFERENCES}

Afriani, Y., Puspaningtyas, Ervira, D., Mahfida, Lailatul, S., Kushartanti, \& Wara. (2017). Asupan Cairan dan Vitamin C dengan Tingkat Kecemasan pada Atlet Sepak Bola di Yogyakarta. Jurnal Media Ilmu Keolahragaan Indonesia, 7(2), 52-55. https://doi.org/10.15294/miki.v7i2.12147

Alaunyte, I., Perry, J., \& Aubrey, T. (2015). Nutritional knowledge and eating habits of professional rugby league players : does knowledge translate into practice. Journal of the International Society of Sports Nutrition, 12(8), 1-7. https://doi.org/10.1186/s12970-015-0082-y

Alfitasari, A., Dieny, F. F., Ardiaria, M., \& , Tsani, A. F. A. (2019). Perbedaan Asupan Energi, Makronutrien, Status Gizi , Dan Vo2 Maks Antara Atlet Sepakbola Asrama dan Non Asrama. Jurnal Media Gizi Indonesia, 14(1), 14-26. https://doi.org/10.204736/mgi.v14i1.14-26

Ameryk, M., Pujanek, M., Augustyniak, A., Szamocka, M., \& Świątkowski, M. (2016). Evaluation of Nutrition and Eating Habits in Children and Adolescents Practicing Football in a Sports Club in Bydgoszcz, Poland. Journal of Education, Health and Sport, 6(13), 11-26. http://dx.doi.org/10.5281/zenodo.229114

Anitasari, N., Ratnawati, D. E., \& Kusuma, T. S. (2019). Optimasi Komposisi Bahan Makanan Atlet Olahraga Menembak dengan Menggunakan Metode Evolution Strategies (ES). Jurnal Pengembangan Teknologi Informasi dan Ilmu Komputer, 3(1), 1005-1011.

Arsani, N. L. K. A., Agustini, N. N. M., \& Sudarmada, I. N. (2014). Manajemen Gizi Atlet Cabang Olahraga Unggulan di Kabupaten Buleleng. Jurnal Sains dan Teknologi, 3(1), 275-287. http://dx.doi.org/10.23887/jst-undiksha.v3i1.2906

Beelen, M., Burke, L. M., Gibala, M. J., \& Loon, L. J. C. Van. (2010). Nutritional Strategies to Promote Postexercise Recovery. International Journal of Sport Nutrition and Exercise Metabolism, 20(6), 515532. https://doi.org/10.1123/ijsnem.20.6.515

Devlin, B. L., Leveritt, M. D., Kingsley, M., \& Belski, R. (2017). Dietary intake, body composition, and nutrition knowledge of Australian football and football players: Implications for sports nutrition professionals in practice. International Journal of Sport Nutrition and Exercise Metabolism, 27(2), 130-138. https://doi.org/10.1123/ijsnem.2016-0191

Dhesa, D. B., Demmalewa, J. Q., \& Abadi, E. (2020). Manajemen Perencanaan Gizi pada Atlet Dayung di Sekolah Menengah Atas Negeri (SMAN) Keberbakatan Olahraga Bahteramas Sulawesi Tenggara. Jurnal Kesehatan Masyarakat Celebes, 1(4), 34-40.

Goulet, E. D. (2012). Dehydration and endurance performance in competitive athletes. Nutrition Reviews, 70(SUPPL/2). https://doi.org/10.1111/j.1753-4887.2012.00530.x 
Hapsari, M., Titis, S., Solichah, K. M., Pratiwi, D., Siagian, C., \& Asyulia, R. (2018). Identifikasi profil antropometri dan pemenuhan zat gizi atlet difabel tenis meja di Indonesia. Jurnal Keolahragaan, 6(2), 162-171. https://doi.org/10.21831/jk.v6i2.15676

Heikkilä, M. (2015). Development of A Nutrition Knowledge Questionnaire for Young Endurance Athletes and Their Coaches. Scandinavian Journal of Medicine \& Science in Sports, 28(3), 873-880. https://doi.Org/10.1111/Ijlh.12426

Irdilla, C. E., Mury, K., Rachmanida, N., \& No, J. A. U. (2016). Hubungan asupan zat gizi, status gizi, aktivitas fisik, dan gaya hidup terhadap daya tahan kardiorespiratori pada mahasiswa UKM Sepakbola Universitas Negeri Lampung tahun 2015. Nutrire Diaita, 8(1), 24-32.

Jamalong, A. (2014). Peningkatan Prestasi Olahraga Nasional Secara Dini Melalui Pusat Pembinaan dan Latihan Pelajar (PPLP) dan Pusat Pembinaan dan Latihan Mahasiswa (PPLM). Jurnal Pendidikan Olahraga, 3(2), 156-168. http://dx.doi.org/10.31571/jpo.v3i2.127

Jeukendrup, A. E., \& R. Randell. (2011). Fat burners: nutrition supplements that increase fat metabolism. Obesity reviews, 12(10), 841-851. https://doi.org/10.1111/j.1467-789X.2011.00908.x

Kurnia, D. I., Kasmiyetti, K., \& Dwiyanti, D. (2020). Pengetahuan Pengaturan Makan Atlet dan Persen Lemak Tubuh terhadap Kebugaran Jasmani Atlet. Sport and Nutrition Journal, 2(2), 56-64. https://doi.org/10.15294/spnj.v2i2.39001

Kuswari, M., Gifari, N., Deandra, F. I., Ali, H. F., Ratibi, A. F. A., Prihastono, E., Yumeida, T., Astuti, D., Masruroh, S., Kusumaningtias, I., Zahraini, Y., Khairunnisa. N., Fauzi, M., Nurhayati, S., Ester, Y., Fatimah, E., Purbaningsih, H., Anggraini, R., \& Tilarso, H. (2021). Buku Pintar Gizi Bagi Atlet. Jakarta: Kementerian Kesehatan RI.

Malara, M., Hübner-Woźniak, E., \& Lewandowska, I. (2013). Assessment of intake and nutritional status of vitamin B1, B2, and B6 in men and women with different physical activity levels. Biology of Sport, 30(2), 117-123. https://doi.org/10.5604/20831862.1044430

Mandosir, Y. M., \& Sinaga, E. (2017). Analisis Sistem Penyelenggaraan Makan SMA Negeri Khusus Olahraga (SMANKOR) Papua. Jurnal Olahraga Papua, 3(1), 19-34.

Mardiana, M., \& Prameswari, G. N. (2019). Pemetaan dan Perumusan Kompetensi Ahli Gizi Bidang Olahraga. Higeia Journal of Public Health Research and Development, 1(3), 625-634. https://doi.org/10.15294/higeia/v3i2/30018

Masdewi., Dewi, M., \& Setiawati, T. (2011). Korelasi perilaku makan dan status gizi terhadap prestasi belajar siswa program akselerasi di SMP. Jurnal Teknologi, Kejuruan, dan Pengajarannya, 34(2), 179190. http://dx.doi.org/10.17977/tk.v34i2.3030

Meng, Y., Manore, M. M., Schuna, J. M., Patton-Lopez, M. M., Branscum, A., \& Wong, S. S. (2018). Promoting healthy diet, physical activity, and life-skills in high school athletes: Results from the wave ripples for change childhood obesity prevention two-year intervention. Nutrients, 10(7). 947. https://doi.org/10.3390/nu10070947 
Mukarromah, S. B., Soegiyanto, Ali, M. A., Rahayu, S., Hadi, \& Yudha, D. W. (2017). Survei Status Gizi Atlet Pplop Provinsi Jawa Tengah Tahun 2017. Jendela Olahraga, 2(2), 77-83. https://doi.org/10.26877/jo.v2i2.1705

Mustamin., Kunaepah, U., \& Ayu, S. D. (2010). Tingkat Pengetahuan Gizi, Asupan dan Status Gizi Atlet di Pusdiklat Olahraga Pelajar Sudiang. Jurnal Media Gizi Pangan, 9(1), 47-51.

Nazhif, G., Rachmanida, N., Mury, K., \& Nabila, T. H. (2016). Relationship Between Nutrition Knowledge and Aerobic Fitness in Young Gymnasts. Science of Gymnastics Journal, 12(2), 195-202.

Ono, M., Kennedy, E., Reeves, S., \& Cronin, L. (2012). Nutrition and culture in professional football. A mixed method approach. Appetite, 58(1), 98-104. https://doi.org/10.1016/j.appet.2011.10.007

Ozdoğan, Y., \& Ozcelik, A. O. (2011). Evaluation of the nutrition knowledge of sports department students of universities. Journal of the International Society of Sports Nutrition, 8(11), 1-7. https://doi.org/10.1186/1550-2783-8-11

Pritchett, K., Bishop, P., Pritchett, R., Green, M., \& Katica, C. (2009). Acute effects of chocolate milk and a commercial recovery beverage on postexercise recovery indices and endurance cycling performance. Applied Physiology, Nutrition and Metabolism, 34(6), 1017-1022. https://doi.org/10.1139/H09-104

Rachmayani, S. A., Kuswari, M., \& Melani, V. (2018). Hubungan Asupan Zat Gizi dan Status Gizi Remaja Putri di SMK Ciawi Bogor. Indonesian Journal of Human Nutrition. 5(2), 125-130. http://dx.doi.org/10.21776/ub.ijhn.2018.005.02.6

Reñón, M. C., \& Collado, P. s. (2015). An assessment of the nutritional intake of football referees. Journal of the International Society of Sports Nutrition, 12(1), 1-7. https://doi.org/10.1186/s12970-015-0068-9

Siregar, N. S., Putra, D., Dani, L., \& Pendahuluan, A. (2018). Hubungan tingkat kecukupan energi dengan status gizi atlet gulat pplp sumatera utara. Jurnal iImiah Ilmu Keolahragaan, 2(1), 10-18. https://doi.org/10.24114/so.v2i1.12871

Spronk, I., Heaney, S. E., Prvan, T., \& Connor, H. T. O. (2015). Relationship Between General Nutrition Knowledge and Dietary Quality in Elite Athletes. International Journal of Sport Nutrition and Exercise Metabolism, 25(3), 243-251. https://doi.org/10.1123/ijsnem.2014-0034

Stufflebeam, D., \& Coryn, C. (2014). Evaluation Theory, Models, And Applications. San Francisco: John Wiley \& Sons.

Syafrizar., \& Welis, W. (2009). Gizi Olahraga. Padang: Wineka Media.

Trakman, G. L., Forsyth, A., Hoye, R., \& Belski, R. (2017). The nutrition for sport knowledge questionnaire (NSKQ): Development and validation using classical test theory and Rasch analysis. Journal of the International Society of Sports Nutrition, 14(1), 1-11. https://doi.org/10.1186/s12970-017-0182-y

Wulandini, P., \& Hamdani, F. (2013). Hubungan Pengetahuan dan Sikap Diet Calon Atlet Terhadap Status Gizi di SMA Negeri Olahraga Provinsi Riau. Journal Sport Area, 2(9), 64-69. https://doi.org/10.25299/sportarea.2017.vol2(1).587 